\title{
Akkermansia muciniphila: Obezite ve Diyabetten Korunmada Yeni Bir Alternatif Olabilir mi?
}

\author{
Havva Polat ${ }^{1}$, Lütfiye Ekici ${ }^{2 *}$ \\ ${ }^{1}$ Erciyes Üniversitesi, Mühendislik Fakültesi, Gıda Mühendisliği Bölümü, Kayseri, Türkiye (ORCID: 0000-0002-7872-3810) \\ ${ }^{2}$ Erciyes Üniversitesi, Mühendislik Fakültesi, Gıda Mühendisliği Bölümü, Kayseri, Türkiye (ORCID: 0000-0002-2216-9128)
}

(Illk Geliş Tarihi 13 Mayıs 2019 ve Kabul Tarihi 4 Temmuz 2019)

(DOI: 10.31590/ejosat.563713)

ATIF/REFERENCE: Polat, H. \& Ekici, L.. (2019). Akkermansia muciniphila: Obezite ve Diyabetten Korunmada Yeni Bir Alternatif Olabilir mi?. Avrupa Bilim ve Teknoloji Dergisi, (16), 533-543.

$\ddot{\mathbf{O} z}$

Akkermansia muciniphila, insan fekal örneğinden yakın tarihte izole edilen ve dikkatleri üzerine çeken gastrointestinal mikrobiyota üyelerinden biridir. Bilimsel çalışmalardan elde edilen sonuçlar, Akkermansia muciniphila' nın diyabet ve obezite gibi günümüzün önemli sağlık sorunlarına karşı alternatif bir çözüm olabileceğini düşündürmektedir. Akkermansia' nın bu etkisi, müsini degrade edebilme yeteneği sayesinde mukus kalınlığını ve bağırsak bariyer bütünlüğ̈nn̈ pozitif şekilde modüle ederek metabolik endotoksemiyi azaltmasından kaynaklanmaktadır. Akkermansia insülin salgılanmasını uyaran GLP-1 hormonunu sekresyonunu arttırarak da etkili olmaktadır. İnsanların beslenme alışkanlıkları, alkol tüketimi, metmorfin ve antibiyotik tedavileri bağırsaktaki Akkermansia yoğunluğunu birebir etkileyen faktörler arasındadır. Bireylerin diyetlerinde yer alan gıdaların polifenol, probiyotik ve prebiyotik içeriklerinin de Akkermansia sayısı üzerine etkilerinin olduğu belirlenmiştir. Bu derlemenin amacı, Akkermansia muciniphila' nın bağırsak florasındaki önemi ve aktivitesi üzerine etkili faktörlerin değerlendirilmesidir. Ayrıca, Akkermansia muciniphila' nın obezite ve diyabet üzerine etki mekanizması konusundaki literatür verilerinin derlenmesi hedeflenmiş̧ir.

Anahtar Kelimeler: Gastrointestinal mikrobiyota, Akkermansia muciniphila, Diyabetes mellitus, Obezite.

\section{Akkermansia muciniphila: Could It Be a New Alternative to Prevention from Obesity and Diabetes?}

\begin{abstract}
Akkermansia muciniphila is one of the members of the gastrointestinal microbiota which has been recently isolated from the human fecal sample and attracted attention. The results obtained from scientific studies suggest that Akkermansia muciniphila may be an alternative solution to today's important health problems such as diabetes and obesity. This effect of Akkermansia result from the reduction of metabolic endotoxemia by modulating the mucus thickness and intestinal barrier integrity positively by the ability to degrade the mucin. Akkermansia is also effective by increasing the secretion of GLP-1 which stimulates insulin secretion. Nutritional habits of people, alcohol consumption, metmorphine and antibiotic treatments are among the factors that directly affect the density of Akkermansia in the intestine. It was determined that the polyphenol, probiotic and prebiotic contents of the foods included in the diets of individuals had effects on the number of Akkermansia. The aim of this review is to evaluate the factors affecting the importance and activity of Akkermansia muciniphila in intestinal flora. In addition, it is aimed to compile the literature data on mechanism of the action of Akkermansia muciniphila on obesity and diabetes.
\end{abstract}

Keywords: Gastrointestinal microbiota, Akkermansia muciniphila, Diabetes mellitus, Obesite.

\footnotetext{
* Sorumlu Yazar: Erciyes Üniversitesi, Mühendislik Fakültesi, Gıda Mühendisliği Bölümü, Kayseri, Türkiye ORCID: 0000-0002-2216-9128, lutfiyed@erciyes.edu.tr
} 


\section{Giriş}

Son çeyrek yüzyılda, insanlar doymuş yağlarca zengin, besinsel lifçe fakir ve yüksek kalorili beslenmeye yönelmişlerdir. Ayrıca insanlar daha az hareket etmeye başlamışlardır. Bu değişimle birlikte obezite ve diyabet gibi metabolik hastalıkların, çocukluk ve adolesan (ergenlik) dönemlerinden başlayarak her yaş döneminde, görülme sıklığı (prevelans) da artmıştır. Araştırmalar aşırı kilolu ve obez bireylerde, kalori kısıtlama ve fiziksel aktivite artışının \%5 -10 arasında kilo kaybı sağladığını göstermektedir. Ancak verilen toplam kilonun neredeyse tamamı, tedaviden yaklaşık beş yıl sonrasına kadar geri alınmaktadır (Everard ve Cani, 2013; Fabersani, Russo, Marquez, Abeijón-Mukdsi, Medina ve Gauffin-Cano, 2018; Kuzu, 2017; McLaughlin, Abbasi, Carantoni, Schaaf ve Reaven, 1999). Bununla birlikte farmakolojik tedaviler de kilo kontrolünde uzun vadede etkili değildir. Son yıllarda yapılan çalışmalar, yararlı mikroorganizmaların obezite, insülin direnci, Tip 1 ve Tip 2 diyabet gibi bazı rahatsızlıkların neden olduğu zararlı etkileri hafifletmek için iyi bir alternatif olduğunu ortaya koymaktadır (Kahn, Hull ve Utzschneider, 2006; Federico, Dallio, Di Sarno, Giorgio ve Miele, 2017; McLaughlin ve Reaven, 2003)

Yakın zamanda keşfedilen intestinal mikroflora üyelerinden biri olan Akkermansia muciniphila' nın yoğunluğu diyabet ve obezite ile ters korelasyon göstermektedir. Hayvan ve insan üzerine yapılan klinik çalışmalardan elde edilen sonuçlar A. muciniphila' nın obezite, diyabet ve ilişkili metabolik bozuklukların önlenmesi ve tedavisi için umut verici, probiyotik bir bakteri olduğunu göstermektedir (Zhou, 2017). Bu derlemede, Akkermansia muciniphila' nın bağırsak florasındaki önemi, aktivitesi üzerine etkili faktörler, obezite ve diyabet gibi günümüzün önemli problemleri üzerine olan olumlu etkileri ele alınmaktadır. Ayrıca tüketilen farklı gıdaların bağırsaktaki $A$. muciniphila yoğunluğu üzerine olan etkileri üzerinde de durulmuştur.

\section{Gastrointestinal mikrobiyota}

Gastrointestinal (GI) kanal, solunum sisteminden sonra vücudumuzdaki en büyük ikinci yüzey alanına sahip kısımdır (Ceyhan, 2012). Bu kanalda kolonize olmuş bakteri, virüs, mantar ve protozoa gibi mikroorganizma gruplarından oluşan mikroflora "intestinal mikrobiyota" olarak adlandırılmaktadır (Haque ve Barritt, 2016). İnsan vücudunda yaşayan bakteri sayısının, insan somatik hücre sayısından 10 kat daha fazla olduğu bilinmektedir (Conlon ve Bird, 2015). İnsanlar GI kanalda 500-1000 kadar bakteri türü taşımaktadır. Bu türlerin çoğu (> \%90) Bacteroidetes ve Firmicutes familyalarına aittir. Bunlara kıyasla daha az kısmını ise Actinobacteria, Fusobakteria, Spirochaetae ve Verrucomicrobia familyalarına ait türler oluşturmaktadır (Chan, Estaki ve Gibson, 2013).

Gastrointestinal kanalın kolonizasyonu doğumdan hemen sonra başlamaktadır (Guarner ve Malagelada, 2003). Bebek ilk olarak annesinin vajenindeki, daha sonrasında ailesindeki ve çevresindeki mikroorganizmalarla karşılaşmaktadır. Böylece bebeğin ilk kolon florası tamamlanmış olmaktadır (Candela ve ark., 2015). Doğum şekli (normal veya cerrahi) ve gestasyonel yaşı (gebelik yaşı) ilk kolon florasının kompozisyonunu etkileyen önemli faktörler arasındadır. Sonraki süreçte annenin beslenme şekli (probiyotik alıp almaması), bebeğin beslenme şekli (anne sütü veya mama tüketimi) mikrofloranın oluşumunu etkilemektedir (García-Peña, Álvarez-Cisneros, Quiroz-Baez ve Friedland, 2017). Mikrobiyal çeşitlilik yaşamın ilk birkaç yılında artmakta ve 2-4 yaşlarında yetişkin florasına ulaşacak şekilde stabilize olmaktadır (Koenig ve ark., 2010). Devam eden zamanda ise genetik faktörler, yaşlanma, beslenme alışkanlıkları, coğrafik köken, yaşam tarzı, düzenli kullanılan ilaçlar ve antibiyotik kullanımı gibi çeşitli faktörler mikrobiyota üzerine etkili olmaktadır. Ayrıca fiziksel aktivite artışının yararlı mikroorganizma yoğunluğunu olumlu yönde etkileyebileceği aktarılmaktadır (Blandino, Inturri, Lazzara, di Rosa ve Malaguarnera, 2016). Sağlıklı bir GI kanalda kolonize olan mikroorganizmaların farklı görevleri vardir. Bunlar;

1. Kolona ulaşan kompleks polisakkaritleri yıkıma uğratarak propiyonat, bütirat ve asetat gibi kısa zincirli yă̆ asitlerini (KZYA) ortaya çıkarmak, kolon epiteli için bu yağ asitlerinin enerji kaynağı olarak kullanımını sağlamak,

2. Patojen mikroorganizmaların çoğalmasına engel olmak,

3. Kolona ulaşan atık maddeleri metabolize ederek vitamin ve kofaktör sentezini yapmak,

4. GI sistem motilitesinin düzenlemesini ve GI sistem vaskülarizasyonunu (damarlanma) sağlamak,

5. Doğal ve adaptif immünitenin gelişmesini sağlayarak, bağışıklık yanıtlarını aktifleştirmek, olarak sıralanabilir (Lee ve Mazmanian, 2010; Özden, 2006; Yetkin, Satış ve Satış, 2017).

GI mikrobiyota sergilediği işlevlerle sindirim, bağışıklık ve hormon sistemleri üzerine etkili olmaktadır. Nitekim GI mikrobiyotada meydana gelebilecek olumsuz değişiklikler bağırsak homeostazını bozarak GI hastalıklar, bulaşıcı bağırsak hastalıkları, karaciğer hastalıkları, mide-bağırsak malignitesi, diyabetes mellitus, alerjik hastalıklar, otizm, metabolik sendrom ve obezite gibi hastalıkların patogenezini (kökenini) oluşturmaktadır. Intestinal mikrobiyotada meydana gelen değişiklikler ve çeşitli hastalıklarla ilişkisi Tablo 1' de özetlenmiştir (Koçak ve Şanlıer 2017; Yılmaz \& Altındiş, 2017).

\subsection{GI Mikrobiyotanın Diyet ve Obezite ile İlişkisi}

Obezite, besinler ile alınan enerjinin, harcanan enerjiden fazla olmasından kaynaklanan ve vücut yağ kitlesi/yağsız vücut kitlesi oranının artması şeklinde ortaya çıkan kronik bir hastalık olarak tanımlanmaktadır (Altunkaynak ve Özbek, 2006). Obezite ile ilgili yapılan araştırmaların sonucunda elde edilen bulgular, GI mikrobiyota içeriğinin, obez bireylerde sağlıklı bireylere kıyasla değiştiğgini ortaya koymaktadır. Obez bireylerin mikrobiyotasında Bacteroidetes sayısı ve Firmicutes/Bacteroidetes oranı azalırken; Lactobacillus sayısı artış göstermiştir (Koçak ve Şanlıer 2017; Yılmaz ve Altındiş, 2017). Bununla birlikte GI mikrobiyota makro besin ögelerini fermente ederek obezite üzerine etki etmektedir. Bağırsak mikrobiyotasında bulunan bakteriler kompleks polisakkaritleri fermente 
ederek KZYA' yı oluşturmaktadır. Bu KZYA bağırsak mukozasından emilip lipit ve glukoz sentezinde kullanılmaktadır. Bunun neticesinde, birey bir günde yaklaşık $100 \mathrm{kcal}$ ek kalori almaktadır. Özetle GI mikrobiyota besinlerin emilimini ve depolanmasını arttırmakta, bunun sonucunda da vücutta enerji artışına, ileri seviyede ise obeziteye neden olmaktadır. Yapılan çalışmalar obez bireylerin bağırsaklarında bulunan KZYA’ larının zayıf bireylere göre \%20 daha fazla olduğunu ortaya koymaktadır (Altuntaş ve Batman, 2017; Koçak ve Şanlıer 2017; Mackowiak, 1982; Tekin, Çiçek ve Konyalıgil, 2018; Schwiertz ve ark., 2010).

Diyabetes mellitus (DM), hücre içi insülin üretiminin tamamen ya da kısmi olarak eksik olması veya çevre dokularda insülin direncinin sebep olduğu kronik hiperglisemi (kan şekeri yüksekliği), karbonhidrat, yăg ve protein metabolizmasında bozukluklar nedeniyle, bu besinlerden yeterince yararlanamama şeklinde seyreden ve bunların sonucunda membran permeabilitesinde değişikliklerin olduğu, aterosklerozun geliştiği metabolizma bozukluğudur (American Diabetes Association, 2014; Koloğlu, 1996). DM dört grup altında sınıflandırılmaktadır. Bu gruplardan üçü; Tip 1 diyabetes mellitus (Tip 1 DM), Tip 2 diyabetes mellitus (Tip 2 DM) ve gestasyonel diyabetes mellitus (GDM) birincil diyabet türü iken, dördüncü grup olan spesifik diyabet türleri ise ikincil diyabet türü olarak bilinmektedir (American Diabetes Association, 2014). Tip 1 DM, genetik yatkınlığı olan bireylerde beslenme faktörleri ve infeksiyon gibi çevresel uyarıcılar sonucunda $\beta$-hücrelerinin hasar görmesiyle mutlak insülin eksikliği sonucu oluşan otoimmün bir hastalıktır. Yapılan çalışmalar disbiyozise olmuş mikrobiyotanın (sağlıksız mikrobiyota) Tip 1 DM' e neden olduğunu kanıtlamaktadır. Tip 2 DM ise genetik yatkınlık, obezite, insülin direnci ve metabolik endotoksemi sonucunda insülin salgılanmasındaki bozukluğun neden olduğu kronik bir hastalıktır. Yüksek kalorili gıda tüketiminin artması buna karşın fiziksel aktivitenin azalması bu hastalığı tetiklemektedir. GI mikrobiyotanın Tip 2 DM üzerine etkisi, KZYA' y1 ve insülin salgılayıcı hormonları etkilemesi ile ilişkilendirilmektedir (Han ve Lin, 2014; Onkano, Vaananen, Karvonen ve Tuomilehto, 1999)

Tablo 1. GI mikrobiyota kompozisyonunda meydana gelen değişikliklere ilişkili hastalıklar

\begin{tabular}{|c|c|c|}
\hline Hastalık & Mikrobiyotadaki Değişiklik & Etki \\
\hline \multirow{3}{*}{ Allerji } & Lactobacillus spp.' da azalma & \multirow{3}{*}{$\begin{array}{l}\text { Bakterilerin erken kolonizasyonu allerjik mediyatörlerin } \\
\text { oluşumunda/ azalmasında önemlidir. }\end{array}$} \\
\hline & Bifidobacterium adolescentis' de azalma & \\
\hline & Helicobacter pylori' de azalma & \\
\hline \multirow[b]{2}{*}{ Çölyak } & Bacteroides vulgatus' da artış & \multirow{2}{*}{$\begin{array}{l}\text { Bakterilerin erken kolonizasyonu, gluten toleransina } \\
\text { neden olabilmektedir. }\end{array}$} \\
\hline & Escherichia coli'de azalma & \\
\hline Gastrik Kanser & Helicobacter pylori'de artış & Dokuda kanser gelişiminde etkilidir. \\
\hline \multirow{4}{*}{ Otizm } & Bacteroidetes'de artış & \multirow{4}{*}{$\begin{array}{l}\text { Kontrol grubuyla karşılaştırıldığında } \\
\text { çeşitliliğinin azaldığı belirtilmektedir. }\end{array}$} \\
\hline & Proteobacteria' da artış & \\
\hline & Actinobacteria' da azalma & \\
\hline & Firmicutes'de azalma & \\
\hline Obezite & Methanobrevibacter smithii' de azalma & $\begin{array}{l}\text { Bağırsakta Gram (-) bakteri sayısının artması sonucu } \\
\text { dolaşımda lipopolisakkarit (LPS) miktarı artmaktadır. } \\
\mathrm{Bu} \text { da endotoksemi ve insülin direncine neden } \\
\text { olmaktadır. }\end{array}$ \\
\hline \multirow{5}{*}{ Tip 2 diyabet } & Firmicutes' de azalma & \multirow{5}{*}{$\begin{array}{l}\text { Bağırsakta Gram (-) bakteri sayısının artması sonucu } \\
\text { dolaşımda LPS miktarı artmaktadır. Bu da endotoksemi } \\
\text { ve insülin direncine neden olmaktadır. }\end{array}$} \\
\hline & Clostridium'da azalma & \\
\hline & Bacteroides-Prevotella' da artış & \\
\hline & Betaproteobacteria' da artış & \\
\hline & Bacteroidetes/Firmicutes oranında artış & \\
\hline \multirow{3}{*}{ Tip 1 diyabet } & Bacteriodes'de artış & \multirow{3}{*}{$\begin{array}{l}\text { İntestinal geçirgenliğin azalması ve inflamasyon } \\
\text { sonucunda pankreas beta hücreleri zarar görmektedir. }\end{array}$} \\
\hline & Firmicutes' de azalma & \\
\hline & Akkermansia' da azalma & \\
\hline Hipertansiyon & Veillonellaceae'da azalma & $\begin{array}{l}\text { Plazmada asetat ve heptanoat seviyelerinin artması ve } \\
\text { mikrobiyal kompozisyon, kan basıncı artışı ile } \\
\text { ilişkilendirilmektedir. }\end{array}$ \\
\hline
\end{tabular}

GI mikroflorada bulunan Gram (-) bakterilerin çoğu patojen özelliktedir. Bu patojeniteye Gram (-) hücre duvarındaki endotoksin özellikteki LPS neden olmaktadır. Obez ve Tip 2 diyabetli hastalarda yüksek yağlı beslenme sonucu plazmada LPS düzeyinin artması, metabolik endotoksemiye neden olmaktadır. LPS, bir enflamasyon reseptörü olan Toll-like 42 reseptörünü (TL-42) insülinin metabolik yolunda aktive etmekte ve insülin sekresyonunu baskılamaktadır. Bu metabolizma sonucunda ise insülin direnci ve daha da ötesinde diyabet ortaya çıkmaktadır (Altuntaş ve Batman, 2017; Cani, Knauf, Iglesias, Drucker ve Delzenne, 2006; Goto ve ark., 1994; Rodes ve ark., 2013).

GI mikrobiyota vücutta inkretin hormon sekresyonunu da etkilemektedir. İnkretin hormon; besin alımı sonucunda GI sistemdeki hücrelerde salgılanarak, insülin sekresyonunu uyaran hormonlardır. Glukagon benzeri peptit-1 (GLP-1) ve gastrik inhibitör polipeptit 
diğer adıyla glukoz bağımlı insülinotropik peptit (GIP) öne çıkan inkretin hormonlardır. GLP-1 ileum (ince bağırsağın en son kısmı) ve kolondaki L hücrelerinden, GIP ise daha üst kısımlarda bulunan $\mathrm{K}$ hücrelerinden salgılanır. Bu iki hormon pankreastaki $\beta$-hücrelerinden insülin sekresyonunu arttırmaktadır. GLP-1 yemek yedikten sonra kan dolaşımına salınır ve GLP-1R (Glukagon benzeri peptit-1 reseptörü) vasıtası ile glukoz bağımlı insülin salgılanmasını ve $\beta$-hücrelerinden insülin biyosentezini uyarıcı etki yapmaktadır. GLP-1 $\beta$-hücresinin kütlesini artırmakta ve glukagon sekresyonunu baskılamaktadır. Ayrıca GLP-1 midenin boşalmasını yavaşlatarak, tokluk hissinin uzun süre hissedilmesini sağlamaktadır. Böylece gıda alımını azaltmakta ve vücut ağırlığının azaltılmasına katkıda bulunmaktadır (Baggio ve Drucker, 2007; Çolak, 2012 ).

Bağırsak mikrobiyotasındaki KZYA, safra asidi ve biyoaktif lipidler gibi bazı metabolitler, enteroendokrin L hücrelerinde eksprese olan GPR41, GPR43 ve TGR5 gibi reseptörleri aktive ederek inkretin hormon salgılanmasını düzenlemektedir. GPR41 reseptörünün asetat tarafindan aktiflenmesi leptin hormonu, GLP-1 ve NYY sekresyonunu arttırmaktadır. GPR43, bütirat veya propiyonat tarafindan aktive edilerek adipogenezi (yağ hücresi oluşumu) arttırmaktadır. TGR5 ise safra asidi reseptörü olup, GLP-1 salımını uyarmaktadır (Kuzu, 2017). GPR119 reseptörü, insanlarda çoğunlukla pankreasta $\beta$-hücreleri ve gastrointestinal sistemde enteroendokrin hücreler tarafından eksprese edilmektedir. İn vitro çalışmalar, GLP-1 salgılanmasının modülasyonunda GPR119' ün bir rolü olduğunu göstermektedir. GPR119' ün fosfolipidler tarafından aktive edilmesi, gıda alımı ve vücut ağırlığı artışında bir azalmaya neden olmaktadır (Overton ve ark., 2006; Overton, Fyfe ve Reynet, 2008). Akkermansia muciniphila, GPR119 reseptörünü aktive eden ligand miktarını arttırması nedeniyle obezite ile ilişkilendirilmektedir (Rodes ve ark., 2013).

\section{Akkermansia mucinipila}

Sağlıklı bir Kafkas kadından alınan dışkı örneğinden izole edilen Akkermansia muciniphila, Verrucomicrobia familyasına ait, müsin degrade edici bir bakteridir (Ottman, Geerlings, Aalvink, De Vos ve Belzer, 2017). Derrien, Vaughan, Plugge, ve De Vos, (2004) tarafından yapılan çalışmada, insan bağırsağındaki müsin bozucu bakterilerin çeşitliliği, kültüre alma ve 16S rRNA analizlerinin kombinasyonuyla araştırılmıştır. Bu çalışmada baskın bir bakteri olan MucT suşu, tek karbon ve nitrojen kaynağı olarak gastrik müsin içeren anaerobik ortamda, dışkı yok olacak şekilde dilüsyon ile izole edilerek, anaerobik yumuşak agar tekniği ile saf bir kültür haline getirilmiş̧tir. MucT suşu, Gram(-), mutlak anaerob, hareketsiz, spor oluşturmayan, oval şekilli bir bakteridir. MucT suşundan elde edilen DNA' nın G (guanin) + C (sitozin) içeriği \% 47. 6 mol olarak bulunmuştur. 16S rRNA gen dizisi analizi, izolatın Verrucomicrobia' nın bir parçası olduğunu ortaya koymuştur. Verrucomicrobia' nın yeni bir genetik türünü temsil eden MucT suşu Akkermansia muciniphila gen. nov., sp. nov. olarak isimlendirilmiştir (Derrien, Vaughan, Plugge ve De Vos, 2004). A. muciniphila, toplam fekal mikrobiyotanın \% 1 - 4' ünü temsil etmektedir (Collado, Derrien, Isolauri, De Vos ve Salminen, 2007; Derrien, Collado, Ben-Amor, Salminen ve De Vos, 2008). Yapılan diğer araştırmalarda da kemirgenler, tavşan, eşek, domuz ve at gibi hayvanların bağırsak mikrobiyotasında $A$. muciniphila varlığı bulgulanmıştır (Kanengoni ve ark., 2015; Liu ve ark., 2014).

GI kanalın gelişimi sırasında oluşan mukus tabakası, bağırsak lümeninin kayganlaştııııı ve koruyucu özelliklerini arttırmaktadır. Mukus tabakası bir yandan bağırsak lümenini korurken, bir yandan da bazı bakteriler tarafından enerji ve karbon kaynağı olarak kullanılmaktadır. Böylece mukozada kolonize olan bakteriler kanaldaki diğer bakteriler ile rekabet etmek zorunda kalmamakta ve konakçı canlıdan gelecek olan besin elemanlarına gerek duymamaktadır. Mukozaya kolonize olabilen bakteriler, konakçıyı zararlı mikroorganizmalardan korurken, mikrobiyotanın yeniden düzenlenmesinde de rol almaktadırlar (Derrien ve ark., 2011; Reid ve ark., 2011). Mukusun ana bileşeni olan müsin, amino asitler ve oligosakkaritlerden oluştuğundan bağırsak bakterileri tarafindan besin kaynağı olarak kullanılmaktadır. Müsinlerin oligosakkarit zincirlerinin parçalanması için gerekli olan enzime sahip olan Akkermansia muciniphila, gösterdiği enzimatik aktivitesi sonucunda müsini degrade etmektedir. Degradasyon sonucunda fukoz, galaktoz, Nasetilglukozamin, N-asetilgalaktozamin, sialik asit, sülfat, disakkarit ve küçük oligosakkaritler açığa çıkmaktadır (Derrien ve ark., 2010; Tailford, Crost, Kavanaugh ve Juge, 2015). Müsin degradasyonu ile mikrobiyotanın enerji ihtiyacı karşılanmaktadır. Böylece açlık, malnütrisyon ve toplam parenteral nütrisyon gibi besin yokluğu durumlarında konakçıya avantaj sağlanmaktadır (Belzer ve De Vos, 2012; Derrien ve ark., 2004). Collado ve ark., (2007) tarafından yapılan çalışmada, fekal müsin konsantrasyonu ile A. muciniphila sayısı arasında negatif bir ilişki olduğu belirtilmektedir.

\subsection{Akkermansia muciniphila' nın Diyabet ve Obezite ile İlişkisi}

Yapılan son çalışmalarda, A. muciniphila bolluğunun vücut ağırlı̆ı, inflamasyon, metabolik sendrom, Tip 1 diyabet ve Tip 2 diyabet ile ters korelasyonu doğrulanmaktadır. Kollektif olarak, hayvan ve insan çalışmalarından elde edilen kanıtların artması, $A$. muciniphila' nın diyabet, obezite ve ilişkili metabolik bozuklukların önlenmesinin yanı sıra bu hastalıkların tedavisi için yüksek kullanılma potansiyeli olan, oldukça umut verici bir probiyotik olduğunu göstermektedir (Zhou, 2017).

A. muciniphila' nın sağlık üzerinde yararlı etkilerinin mekanizmaları tam olarak aydınlatılmamasına rağmen, mukus kalınlığının ve bağırsak bariyer bütünlüğünün $A$. muciniphila tarafindan pozitif modülasyonunun, bu bakteriye probiyotik karakter kazandırdığı düşünülmektedir. Obez ve Tip 2 diyabetli farelerin tedavisinde $A$. muciniphila takviyesinin değerlendirildiği bir çalışmada, mukus kalınlı̆̆ının yeniden düzenlendiği, serum LPS ve metabolik endotokseminin azaldığı belirlenmiştir (Everard ve ark., 2013). NOleoylethanolamide (OEA) ve 2-oleoyl glycerol (2-OG) gibi biyoaktif lipitler, GPR119 reseptörünün ligandlarıdır. GPR119 reseptörü, insülin sekresyonunu uyaran GLP-1 hormonunun salgılanmasını uyarmaktadır. Yapılan bir çalışmada Akkermansia muciniphila uygulamasının, biyoaktif lipid 2-OG’ nin bağırsak düzeylerini önemli ölçüde arttırdığı saptanmıştır (Rodes ve ark., 2013).

Akkermansia muciniphila' nın diyabet ve obezite ilişkisini incelemek için hayvan ve insan üzerinde birçok çalışma yapılmıştır. Öncelikle, hayvan çalışmalarına değinilecektir. Tarafımızdan yapılan literatür taramalarında, son yıllarda metabolik bozukluğa sahip farelerde A. muciniphila takviyesinin etkisini ve metabolik bozukluklarla olan ilişkisini inceleyen yayınların sayınındaki artış dikkat çekicidir. Apolipoprotein E (ApoE), çok düşük yoğunluklu lipoprotein (VLDL) ve düşük yoğunluklu lipoproteinlerin (LDL) karaciğer 
ve dokulara taşınmasında görev alan, VLDL ve LDL reseptörlerinin ligandı olarak işlev gören bir yapıdır (Bayly, 2014). A.muciniphila takviyesinin ateroskleroz üzerindeki etkisini araştıran bir çalışmada, ApoE yapısından eksik (Apoe -/-) farelere 8 hafta boyunca yüksek yağlı batı diyeti uygulamasının, dışkıdaki A.muciniphila yoğunluğunu $7.0 \times 10^{9} / \mathrm{g}$ dışkı' dan $4.6 \times 10^{9} / \mathrm{g}$ dışkı seviyesine düşürdüğü

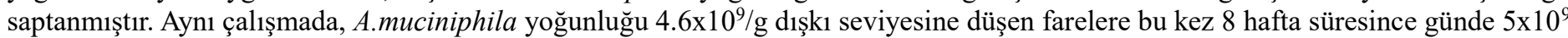
kob A. muciniphila takviyesinin ise bu bakterinin yoğunluğunu yağlı diyet öncesindeki miktarına yeniden yükselttiği bildirilmektedir. $\mathrm{Bu}$ çalışmada ayrıca A.muciniphila takviyesinin bağırsak bütünlüğünü yeniden düzenleyerek, ateroskleroza neden olan inflamasyon ve metabolik endotoksemiyi azalttığı saptanmıştır (Li, Lin, Vanhoutte, Woo, ve Xu, 2016; ). Everard ve ark., (2013) tarafindan obezite ve Tip 2 diyabet ile A. muciniphila arasındaki ilişkinin araştırıldığı bir çalışmada, diyetle indüklenen obez (DIO) farelere oral yolla 4 hafta boyunca $2 \times 10^{8} \mathrm{kob} A$. muciniphila takviyesi yapılmıştır. Bu çalışmada, A. muciniphila takviyesinin yüksek yağlı diyetle beslenen DIO farelerin dışkı içeriğindeki $A$. muciniphila yoğunluğunu $10^{8} \mathrm{~g} /$ dışkı' dan $10^{10} / \mathrm{g}$ dışkı' ya yükselttiği tespit edilmiştir. Canlı $A$. muciniphila takviyesi ile DIO farelerde metabolik endotokseminin ve yağ kütlesi/ yağsız kütle oranının azaldığı gösterilmiştir. Ayrıca canlı A. muciniphila takviyesinin kana glukoz verilmesini sağlayan glukoz-6-fosfataz enziminin ekpresyonunu \%40 oranında baskılayarak hiperglisemi ve insülin direncinde azalmaya neden olduğu kanıtlanmıştır. Her iki çalışmada da yüksek yağlı diyet mikrobiyotanın disbiyozisine neden olduğu saptanırken, A.muciniphila takviyesinin diğer mikrobiyota üyelerinde herhangi bir değişikliğe neden olmadığı bulgulanmıştır (Li ve ark., 2016; Shin ve ark., 2014).

Serum LPS düzeyindeki herhangi bir artış, çoğunlukla bağırsak bariyerinin işlevini kaybettiğini ve sızıntı yaptığını göstermektedir. Müsin tabakasının kalınlığı ise bağırsak geçirgenliğinin önemli bir ölçütüdür (Zhou, 2017). Araştırmalar, yüksek yağlı diyetle beslenen DIO farelerin, normal diyetle beslenenlere kıyasla \% 46 daha ince bir mukus tabakasına sahip olduğunu göstermektedir (Everard ve ark., 2013). Yapılan çalışmalar A. muciniphila takviyesinin müsin tabakasının kalınlığını arttırdığını, bunun sonucunda da bağırsak geçirgenliğinin azalmasına bağlı olarak dolaşıma giren LPS miktarının azaldığını ortaya koymaktadır (Everard ve ark., 2013; Li ve ark., 2016).

Diyetle indüklenen obez (DIO) farelerde yapılan bir diğer çalı̧̧ada ise 4 haftalık yüksek yağlı diyetle beslenmelerinin ardından farelerde A. muciniphila sayısının düştüğü saptanmıştır. Daha sonra aynı farelere A. muciniphila 6 hafta boyunca günlük 4.0x10 ${ }^{8} \mathrm{kob}$ düzeyinde verildiğinde bağırsaktaki sayının geri kazanıldığı belirlenmiștir. Ancak yüksek yağlı diyetle beslenen DIO farelerde vücuda oral yolla $4.0 \times 10^{6} \mathrm{kob}$ düzeyinde $A$. muciniphila alımının glikoz toleransını iyileştirmediği gözlenmiştir. Bu sonuç $A$. muciniphila için yanıt limiti olacak belirli bir doz miktarının bulunduğunu düşündürmektedir (Shin ve ark., 2014).

A. muciniphila inokülasyonunun metabolik parametreler üzerindeki etkisini araştırmak için obeziteye eğilimli bir fare suşunun (AxB19) kullanıldığı bir çalışmada, erkek AxB19 farelerine 4 hafta boyunca yüksek yağ ve yüksek sakaroz içeren bir diyet uygulanmıştır. Bunu takiben, fareler bir hafta süreyle günde $10^{9}$ kob düzeyinde $A$. muciniphila ile beslenmiştir. Bu takviyeden sonra farelerin vücut ağırlığı, vücut yağı ve insülin direnci parametrelerinde önemli bir azalma olduğu ifade edilmiştir (Org ve ark., 2015).

İnsanlarla yapılan çalışmalarda da obezite ve diyabetin A. muciniphila sayısına olan etkisi araştırılmıştır. Obezite, insülin direnci, inflamasyon ve yağ metabolizması ile ilişkili bağırsak metagonomik işaretleyicilerini (marker) tanımlamak amacıyla yapılan çalışmada, Danimarkalı obez kadınlarda, serum total ve LDL kolesterol miktarındaki artış ile $A$. muciniphila' nın negatif ilişkili olduğu, beslenmede yağ alımının artması ile dışkıdaki A. muciniphila sayısının azaldığı kanıtlanmaktadır (Brahe ve ark., 2015)

Clarke ve ark., (2014) tarafından yapılan çalışmada diyet ve egzersizin bağırsak mikrobiyotası üzerindeki etkisi incelenmiştir. Çalışmanın sonucunda aktif sporculardaki A. muciniphila sayısının, vücut kitle indeksi (BMI) yüksek olan $\left(32 \mathrm{~kg} / \mathrm{m}^{2}\right)$ bireylere kıyasla daha yüksek olduğu belirtilmiştir. Kolombiyalı deneklerde BMI artışı ile mikrobiyota arasındaki ilişkiyi inceleyen bir diğer çalışmada Akkermansia' nın BMI ile negatif korelasyon gösterdiği sonucuna varılmıştır (Escobar, Klotz, Valdes, ve Agudelo, 2015). Obez, aşırı kilolu ve zayıf, 4-5 yaş aralığındaki çocuklarda yapılan bir çalışmada da diğer çalışmalara benzer şekilde obez ve aşırı kilolu çocuklarda Akkermansia yoğunluğunun düşük olduğu gösterilmiştir (Karlsson ve ark., 2012). Altı haftalık kalorili kısıtlaması öncesi ve sonrasında intestinal mikrobiyota, metabolik sendrom ve diyet arasındaki ilişkiyi inceleyen bir çalışmada, A. muciniphila yoğunluğunun aşırı kilolu ve obez bireylerde, açlık glukozu, bel-kalça oranı ve subkutan (deri altı) adiposit hücre çapı ile negatif korelasyon gösterdiği belirtilmektedir. Aynı çalışmada daha fazla A. muciniphila verilen bireylerin, daha iyi insülin duyarlılığına ve metabolik profile sahip olduğu gösterilmektedir (Dao ve ark., 2015). Bağırsak mikrobiyotasınının Tip 2 DM ile ilişkisini araştırmak için yapılan çalışmada glukoz intoleransı durumuna göre, normal glukoz toleransı (NGT), DM öncesi (pre-DM) ve yeni teşhis edilmiş Tip 2 DM olmak üzere 3 grup oluşturulmuştur. Akkermansia muciniphila sayısının NGT grubunda, pre-DM grubundakine göre daha fazla olduğu bulgulanmıştır. Ayrıca Verrucomicrobiae 'nın hem pre-DM hem de Tip 2 DM gruplarında anlamlı olarak daha düşük sayıda sahip olması, bu familyanın Tip 2 DM için belirteç olabileceği belirtilmiştir (Zhang ve ark., 2013).

Gebelikte kilo alımının intestinal mikrobiyota üzerine olan etkisini inceleyen çalışmalarda ise bazı tutarsız sonuçlar göze çarpmaktadır. İspanyol gebe kadınlarda bağırsak mikrobiyotası, vücut ağırlığı, kilo alımı ve biyokimyasal parametreler arasındaki ilişkiyi açıklamayı amaçlayan çalışmada, Akkermansia' nın hamilelik sırasında daha fazla kilo alan kadınlarda daha az olduğunu belirtilmektedir (Santacruz ve ark., 2010). Bu çalışmaya karşıt çalışmalardan birinde, Finlandiyalı deneklerde kilolu annelerin bebeklerinin, normal kilolu annelerin bebeklerinden daha fazla Akkermansia barındırdı̆̆ı ortaya konmuştur ( Collado, Isolauri, Laitinen ve Salminen, 2010). Bir başka çalışmada ise aşırı kilolu hamilelerde, normal kilolu hamilelere kıyasla daha fazla Akkermansia olduğu belirtilmektedir. Ayrıca bu çalışmada hamilelikte aşırı kilo alımı ile Akkermansia yoğunluğunun azaldı̆̆ı ifade edilmektedir (Collado, Isolauri, Laitinen ve Salminen, 2008). Elde edilen verilerin tutarsız olması nedeni ile gebelik sürecindeki kilo alımına bağlı olarak Akkermansia yoğunluğunun nasıl etkilendiği net bir şekilde açıklanamamaktadır.

\section{Akkermansia muciniphila yoğunluğunu etkileyen faktörler}




\subsection{Probiyotik ve prebiyotik takviyeleri}

Probiyotikler yeterli miktarlarda tüketildiğinde doğal bağırsak florasının özelliklerini geliştirerek ve/veya gastrointestinal sistemin metabolik aktivitesini değiştirerek tüketici sağlığını yararlı şekilde etkileyen canlı mikroorganizmaların tek ya da karışık kültürlerinden oluşan mikrobiyal gıda takviyeleridir (Özyurt ve Ötles, 2014). Probiyotiklerin obezite ve diğer metabolik hastalıklara etkisi bağırsaktaki bakteri kompozisyonunu değiştirmesiyle açıklanmaktadır. Probiyotik takviyesi toplam bakteri yükünü arttırmaktadır (Goossens ve ark., 2003; Tannock, Munro, Harmsen, Welling ve Smart, 2000). Doğal bağırsak florası tarafından seçici olarak fermente edilebilen, GI floranın kompozisyonu ve/veya aktivitesini etkileyerek, bireye iyi olma hali ve bireyin sağlı̆̆ üzerinde olumlu etkiler gösteren besin bileşenleri ise prebiyotik olarak tanımlamaktadır (Guarner ve ark., 2017). Prebiyotik özelliğe sahip gıda bileşenlerinin çoğunluğunu karbonhidrat yapıdaki fruktooligosakkaritler (FOS), inülin ve galaktooligosakkaritler oluşturmaktadır. Bu prebiyotikler muz, elma, çilek, enginar, kuşkonmaz, soya fasulyesi, tam buğday, arpa, keten tohumu, badem ve ceviz gibi gıdalarda doğal olarak bulunmaktadır. Prebiyotik açısından zengin bu gıdalar obeziteye karşı önemli alternatifler arasındadır (Choque Delgado ve Tamashiro, 2018). Prebiyotiklerin KZYA miktarında artış sağlayarak, motilite ve gastrointestinal fonksiyonu iyileştirerek, ayrıca GI kanal ile ilişkili bağışıklık sistemi dokularını güçlendirerek bağırsaktaki immün ve metabolik fonksiyonlar üzerine faydalı etki göstermektedir (Schley ve Field , 2003; Roberfroid ve ark., 2010).

Tüketilen probiyotik ve prebiyotiklerin bağırsak florasındaki $A$. muciniphila yoğunluğu üzerine etkilerini inceleyen az sayıda çalışma bulunmaktadır. Bunlardan birinde, karışım olarak verilen probiyotiklerin A. muciniphila üzerine etkisini inceleyen in vitro bağırsak modeli ile yapılan çalışma, probiyotik ilavesinin kolon boyunca toplam KZYA'larını zamana bağlı olarak arttırdığını göstermektedir. KZYA'ları müsin kalınlaşmasını teşvik etmektedir. KZYA 'ların artması, müsin degrade edici bir bakteri olan $A$. muciniphila' nın gelişimine katkıda bulunmaktadır (Zhou, 2017).

Yüksek yağlı beslenen diyetle indüklenen obez (DIO) ve insülin direncine sahip fareler ile yapılan bir çalışmada, farelere Lactobacillus rhamnosus LMG S-28148 ve Bifidobacterium animalis subsp. lactis LMG P-28149 suşlarının her birinden 14 hafta boyunca $5 \times 10^{8}$ kob olacak şekilde takviye edilmiştir. Çalışma sonucunda, KZYA üretimi sayesinde dışkı içeriğinde A. muciniphila yoğunluğunun yaklaşık 100 kat arttığı ve insülin direncinin iyileştiği belirtilmektedir. Bu çalışmada ayrıca, vücut ağırlığı artışı ile $A$. muciniphila yoğunluğu arasında ters korelasyon olduğu gösterilmektedir (Alard ve ark., 2016). Kong, Gao, Yan, Huang ve Qin, (2018) tarafından yapılan bir diğer çalışmada, yüksek yağlı ve yüksek sükrozlu diyet uygulanan farelerde azalan $A$. muciniphila sayısının, Lactobacillus acidophilus, Bifidobacterium longum ve Enterococcus faecalis (1:1:1) oranındaki karışımın 2.0 x $10^{7} \mathrm{kob} / \mathrm{gün}$ doz olarak uygulanması ile yeniden arttığı gösterilmiştir.

Everard ve ark., (2013) tarafından, obezite ve Tip 2 diyabetin A. muciniphila arasında ilişki ile ilgili yaptıkları çalışmada, prebiyotik takviyesinin de etkisi araştırılmıştır. Bu amaçla DIO farelere 8 hafta boyunca \% 60 yağ içeren yüksek yağlı diyet uygulanmıştır. Bunun sonucunda dışkıdaki A. muciniphila sayısında $100 \mathrm{~kat}$ azalma (başlangıçta $10^{9} / \mathrm{g}$ dışk1 iken, $10^{7} / \mathrm{g}$ dışkı seviyesine düşüş) olmuştur. Bu çalışmada günlük $0.3 \mathrm{~g}$ FOS takviyesinin azalan A. muciniphila yoğunluğunu $10^{9} / \mathrm{g}$ dişkıya yükselttiği kanıtlanmışır. Aynı çalışmada FOS takviyesinin leptin yetersizliği olan farelerde daha etkili olduğu belirtilmiştir. Leptin yetersizliği olan bu farelerde 5 hafta boyunca $0.3 \mathrm{~g} /$ gün FOS takviyesi $A$. muciniphila $1000 \mathrm{~kat}$ arttırdı̆̆ $1\left(10^{2} / \mathrm{g}\right.$ dışkıdan $10^{10} / \mathrm{g}$ dışkıya) gösterilmiştir.

Prebiyotik takviyesinin, yeni doğmuş erkek Sprague-Dawley ratlar üzerinde kilo alımı üzerine etkisini incelemek amacıyla yapılan çalışmada, ratlara 16 hafta boyunca \% 10'luk kısmı oligofruktozdan oluşan bir diyet uygulanmıştır. Oligofruktoz takviyesinin besin alımını ve vücut ağırlığını etkilemeden, A. muciniphila yoğunluğunu artırdığı saptanmıştır (Reid, Eller, Nettleton ve Reimer, 2016). Farelerde yapılan bazı çalışmalarda FOS takviyesinin, serum LPS seviyesini önemli ölçüde azalttığ (\% 50'nin üzerinde) ve glisemik kontrolde belirgin bir iyileşme sağladığı kanıtlanmaktadır (Everard ve ark., 2011, 2013). FOS dışındaki inülin, glukan, galaktooligosakkarit gibi prebiyotik takviyelerinin A. muciniphila gelişiminde önemli bir etkisinin olmadığı belirtilmektedir. Bu da FOS'un A. muciniphila tarafından tercih edilen bir besin olabileceğini düşündürmektedir (Zhou, 2017).

\subsection{Diyet Polifenol Takviyesi}

Diyet polifenolleri doğal antioksidanlar olup, aynı zamanda güçlü antimikrobiyal aktiviteye de sahiptir (Daglia, 2012; Parkar, Stevenson ve Skinner, 2008). Diyet polifenollerinin antioksidan ve antimikrobiyal aktivitesi bağırsak mikrobiyotasını yeniden düzenleyebilmektedir. Çünkü $A$. muciniphila gibi birçok bağırsak bakterisi, serbest oksijen radikallerinin etkisi altında son derece savunmasız olan zorunlu anaeroblardır (Daglia, 2012). Diyet antioksidanları, serbest oksijenleri bağlayarak anaerob bakteriler için ortam hazırlayarak, bu bakterileri korumaya ve bağırsak mikrobiyotalarını değiştirmeye yardımcı olmaktadır (Roopchand, Carmody, Kuhn ve Moskal, 2015). Nitekim Kemperman ve ark., (2013) yaptığı çalışma, kompleks polifenol karışımları içeren siyah çayın ve kırmızı şaraplık üzüm özütünün, bağırsağın mikrobiyal ekosisteminde A. muciniphila' nın büyümesini önemli ölçüde desteklediğini göstermektedir.

Besin polifenollerinin bağırsaktaki A. muciniphila' nın büyümesi üzerindeki etkisini inceleyen çalışmalarda tutarsız sonuçlara rastlanmaktadır. Bu çalışmalardan birinde, yüksek yağlı beslenmiş diyetle indüklenen obez farelere Concord üzüm polifenolleri takviye edildiğinde $A$. muciniphila yoğunluğunun \% 6.2' den \% 49.1' e yükseldiği belirtilmektedir (Roopchand ve ark., 2015) . Diğer bir çalışmada kızılcık özü oluşan takviyenin, dışkıda A. muciniphila yoğunluğunu \% 2' den \% 30'a yükselttiği bildirilmektedir (Kemperman ve ark., 2013). Buna karşın bazı çalışmalar, nar ekşisi, yeşil çay ekstresi ve bütün haldeki Kaliforniya sofralık üzüm takviyesinin ise sağlıklı insanların veya DIO farelerinin $A$. muciniphila yoğunluğu üzerinde hiçbir etkisinin olmadığını göstermektedir. Bu tutarsız sonuçlar, diyet polifenollerin A. muciniphila üzerine etkilerinin kimyasal yapıları ve kaynaklarına bağlı olarak değişebileceğini göstermektedir. Yeşil çay polifenollerinin, Akkermansia yoğunluğu üzerinde herhangi bir etkisi belirlenemez iken, yüksek yağlı beslenen obez farelerde vücut ağırlığı artışının ve diğer metabolik sorunların etkisini azalttığı bildirilmektedir (Anhê ve ark., 2015; Axling ve ark., 2012 ). Ayrıca nar ekstraktları, dışkıdaki A. muciniphila yoğunluğunu değiştirmemesine rağmen, bu bakterinin nar metaboliti olan 
ürolitini üretebilen deneklerin dışkı örneklerinde, üretemeyenlere kıyasla 33-47 kat daha fazla bulunduğu belirtilmektedir. Bu durum, A. muciniphila' nın, bağırsaktaki fenolik bileşiklerin parçalanmasında önemli bir rol oynayabileceğini göstermektedir (Baldwin ve ark., 2017).

\subsection{FODMAP Takviyesi}

"FODMAP", fermente olabilen fruktoz, laktoz, oligo-, di- ve monosakkaritler ile poliolleri (sorbitol, mannitol, ksilitol ve maltitol) ifade etmektedir. Bu yapılar, ince bağırsakta yetersiz emildikleri ve diyet lifleri ile karşılaştırıldığında kısa zincirli doğaları gereği kolondaki bakteriler tarafından daha hızı fermente edilmektedir (Gibson ve Shepherd, 2005). FODMAP' in A. muciniphila yoğunluğu üzerine etkilerinin incelendiği araştırma sayısı son derece az olmakla birlikte, insanlar üzerinde yapılan çalışmalar diyetteki FODMAP içeriği ile A. muciniphila sayısı arasında pozitif bir ilişki olduğunu ortaya koymaktadır (Halmos ve ark., 2015, 2016).

\subsection{Yüksek Yağlı Beslenme ve Alkol Tüketimi}

Yapılan çalışmalar, yüksek yağlı diyetin, farklı hayvan modellerinde A. muciniphila yoğunluğunu önemli ölçüde azalttığını göstermektedir (Anhê ve ark., 2015; Axling ve ark., 2012; Chan, Estaki ve Gibson, 2013; Li ve ark., 2015). DIO farelerinde 8 hafta boyunca yüksek yağlı diyet (\%60 yağ) uygulaması, A. muciniphila' nın 100 kat azalmasına neden olmaktadır (Chan ve ark., 2013). Alkol alımı da A. muciniphila' yı olumsuz etkilemektedir. Nitekim DIO farelerde alkol uygulaması ( $\% 30 \mathrm{w} / \mathrm{v}, 6 \mathrm{~g} / \mathrm{kg}$ vücut ağırlı̆̆ı), $A$. muciniphila' nın fekal mikrobiyota içerisindeki nispi bolluğunu 100 kat azalmasına yol açmaktadır (Neyrinck ve ark., 2017).

\subsection{Metformin Tedavisi}

Metformin, Tip 2 DM tedavisi için kullanılan primer ilaçtır. Hayvanlar ile yapılan çalışmalar, metforminin bağırsak mikrobiyotasını modüle edebildiğini ve bu işlevin anti-enflamatuar, anti-obezite ve glikoz metabolizması üzerindeki terapötik özelliği ile ilişkili olduğunu ortaya koymaktadır (Napolitano ve ark., 2014; Nauck, Frid, Hermansen ve Shah, 2009). Tüm hayvan çalışmaları, metforminin A. muciniphila yoğunluğunu önemli ölçüde desteklediğini göstermektedir.

Shin ve ark., (2014) yaptıkları çalışmada, yüksek yağ ile beslenen DIO farelere $300 \mathrm{mg} /$ vücut ağırlığı oranında metformin tedavisi uygulanmıştır. Çalışma sonucunda yüksek yağlı beslenme sonucunda azalan Akkermansia yoğunluğunun arttırdığı belirtilmektedir. Ayrıca glisemik kontrolde iyileşme sağlandığı ve serum LPS' de azalma olduğu gösterilmiştir. Zhou ve ark., (2016) yaptıkları çalışmada yüksek yağ ile beslenen farelere $100 \mathrm{mg} /$ vücut ağırlığı/gün metmorfin tedavisi uygulanmıştır. Tedavi sonucunda Akkermansia yoğunluğu ye yeniden düzenlenmiştir. Bir başka çalışmada, yine yüksek yağ diyeti uygulanan DIO fareler $300 \mathrm{mg} / \mathrm{vücut} \mathrm{ağırlığı} \mathrm{şeklinde}$ metformin ile tedavi edilmiştir. Sonuç olarak, Akkermansia yoğunluğunun dışkıda $\% 0.7$ ' den $\% 12.4$ ' ye yükseldiği ve metabolik profilin iyileştiği belirtilmektedir (Lee ve Ko, 2014). Bu çalışmalardaki en önemli bulgulardan biri de, metformin tedavisi öncesinde yüksek yağlı beslenen fareler üzerinde bir antibiyotik kombinasyonu uygulanmasının, metformin aktivitesini yükseltmesidir. Metformin tedavisi, müsin üreten goblet hücrelerinin sayısını dolayısıyla da A. muciniphila yoğunluğunu arttırmaktadır (Everard ve ark., 2013). Bu bulgular metforminin antidiyabetik aktivitesinin, bağırsak mikrobiyotasının düzenlenmesinde ki etkisini, özellikle A. mucininiphila artışına ve serum LPS seviyelerinde azalmaya neden olduğunu, bunun sonucunda da inflamasyonu ve metabolik bozuklukları azalttığı hipotezini ortaya koymaktadır (Zhou, 2017).

\subsection{Antibiyotik tedavisi}

Antibiyotik tedavileri genellikle bağırsakların bakteri çeşitliliğinde önemli değişimlere neden olmaktadır. Antibiyotiklerin kimyasal yapısı, tedavi süresi ve dozu ile mikrobiyotadaki bakterilerin direnç seviyesi bu değişikliklerin boyutunu etkilemektedir (Manichanh ve ark., 2013; Hooper ve Gordon, 2001). Fareler ve insanlar üzerinde yapılan çalışmalar antibiyotik tedavisinin, bağırsaktaki $A$. muciniphila gelişimini nispi olarak desteklediğini ortaya koymaktadır. Gram-pozitif bakterilere karşı kullanılan bir glikopeptid antibiyotik olan vankomisinin, obez almayan (NOD) farelerde immün homeostazı ve diyabetik semptomların gelişimi üzerine etkilerininin araştırıldığı bir çalışmada Verrucomicrobia sayısını baskılayan Firmicutes ve Bacteroidetes sayısında önemli ölçüde azalmaya neden olduğu belirtilmektedir (Hansen ve ark., 2012). Diğer bir çalışmada ise geniş spektrumlu antibiyotik tedavisinin A.muciniphila üzerine olan etkileri araştırılmıştır. Bu amaçla bir özofagus komplikasyonu olan Coxiella burnetii enfeksiyonu geçiren hasta deneklere doksisiklin (400 mg/gün), hidroksiklorokin (600 mg/gün), piperasilin/tazobaktam (12 g/gün) ve teikoplanin (600 $\mathrm{mg} /$ gün) tedavisi uygulanmıştır. Tedavi sonucunda dışkıdaki toplam bağırsak mikrobiyotasının \% $40^{\prime}$ 'nın A.muciniphila olduğu saptanmıştır (Dubourg ve ark., 2013). İn vitro antibiyotik duyarlılık testleri, A. muciniphila' nın imipenem, piperasilin/tazobaktam ve doksisiklin gibi bazı antibiyotiklere duyarlı iken vankomisin, metronidazol ve penisilin G' ye karşı ise dirençli olduğunu ortaya koymaktadır (Pérez-Cobas ve ark., 2012).

\section{Sonuç}

Gastrointestinal mikrofloranın obezite ve diyabetes mellitus hastalıkları ile ilişkisi olduğunu gösteren veriler dikkate alındığında, bağırsak mikrobiyotasındaki yararlı bakterilerin bu hastalıkların tedavisinde kullanılması uygun bir alternatif olarak öne çıkmaktadır. Hayvanlarda ve insanlarda yapılan klinik çalışmalar bağırsak mikrobiyotasının önemli üyelerinden olan Akkermansia muciniphila'nın diyabet ve obezite ile negatif ilişkili olduğunu ortaya koymaktadır. Gıdaların polifenol, probiyotik ve prebiyotik içeriği, insanların beslenme alışkanlıkları, metmorfin ve antibiyotik tedavisi Akkermansia üzerinde etkili faktörlerdir. Bazı polifenoller, Akkermansia gelişiminde olumlu etki gösterirken; bazıları herhangi bir etki göstermemektedir. Yüksek yağlı beslenme, alkol tüketimi Akkermansia sayısını azaltırken; probiyotik ve prebiyotik takviyesi ile metformin kullanımı Akkermansia sayısında artışa neden olmaktadır. Antibiyotik tedavisi ise bağırsak florasında değişime neden olarak, Akkermansia sayısını nispi olarak çoğaltmaktadır. 
Sonuç olarak, farklı diyetlerin bağırsaktaki Akkermansia sayısı üzerine olan etkilerinin yanı sıra A. muciniphila' nın diyabet ve obezite ile ilişkisini açıklayan mekanizmaların net olarak aydınlatılacağı çalışmalara gereksinim duyulmaktadır. Elde edilen sonuçlar doğrultusunda Akkermansia muciniphila takviyesinin obezite ve diyabet tedavisinde ve/veya önlenmesinde alternatif bir yöntem olarak kullanılabileceği düşünülmektedir.

\section{Kaynakça}

Alard, J., Lehrter, V., Rhimi, M., Mangin, I., Peucelle, V., Abraham, A. L., \& Grangette, C. (2016). Beneficial metabolic effects of selected probiotics on diet-induced obesity and insulin resistance in mice are associated with improvement of dysbiotic gut microbiota. Environmental Microbiology, 18(5), 1484-1497. https://doi.org/10.1111/1462-2920.13181

Altunkaynak, B. Z., \& Özbek, E. (2006). Obezite: Nedenleri ve tedavi seçenekleri. Van Tip Dergisi, 13(4), 138-142.

Altuntaş, Y., \& Batman, A., (2017). Mikrobiyota ve metabolik sendrom. Türk Kardiyoloji Derneği Arşivi 45(3), 286-296. https://dx.doi.org/10.5543/tkda.2016.72461

American Diabetes Association. (2014). Diagnosis and classification of autoimmune diabetes mellitus. Diabetes Care, 37(1), 81-90. https://doi.org/10.2337/dc14-S081

Anhê, F.F., Roy, D., Pilon, G., Dudonné, S., Matamoros, S., Varin, T.V., Garofalo, C., Moine, Q., Desjardins, Y., Levy, E., \& Marette, A.(2015). A polyphenol-rich cranberry extract protects from diet-induced obesity, insulin resistance and intestinal inflammation in association with increased Akkermansia spp. population in the gut microbiota of mice. Gut, 64(6), 872-883. https://doi.org/10.1136/gutjnl-2014-307142

Axling, U., Olsson, C., Xu, J., Fernandez, C., Larsson, S., Ström,K., Ahrné, S., Holm, C., Molin, G., \& Berger, K. (2012). Green tea powder and Lactobacillus plantarum affect gut microbiota, lipid metabolism and inflammation in high-fat fed C57BL/6J mice. Nutrition and Metabolism, 9(1), 1-18. https://doi.org/10.1186/1743-7075-9-105

Baggio, L. L., \& Drucker, D. J. (2007). Biology of incretins: GLP-1 and GIP. Gastroenterology, 132(6), $2131-2157$. https://doi.org/10.1053/j.gastro.2007.03.054

Baldwin, J., Collins, B., Wolf, P. G., Martinez, K., Shen, W., Chuang, C. C., Zhong, W., Cooney, P., Cockrell, C., Chang, E., Gaskins H. R., McIntosh, M. K. (2017). Table grape consumption reduces adiposity and markers of hepatic lipogenesis and alters gut microbiota in butter fat-fed mice. The Journal of Nutritional Biochemistry, 27, 123-135. https://doi.org/10.1016/j.jnutbio.2015.08.027

Bayly, G. R. (2014). Lipids and disorders of lipoprotein metabolism. William J. Marshall, Marta Lapsley, Andrew P. Day\& Ruth M. Ayling (Ed.), In Clinical Biochemistry: Metabolic and Clinical Aspects (s. 702-736) içinde. Churchill Livingstone

Belzer, C., \& De Vos, W. M. (2012). Microbes inside from diversity to function: The case of Akkermansia. ISME Journal,6(8),14491458. https://doi.org/10.1038/ismej.2012.6

Blandino, G., Inturri, R., Lazzara, F., DiRosa, M., \& Malaguarnera, L. (2016). Impact of gut microbiota on diabetes mellitus. Diabetes and Metabolism, 42(5), 303-315. https://doi.org/10.1016/j.diabet.2016.04.004

Brahe, L. K., Le Chatelier, E., Prifti, E., Pons, N., Kennedy, S., Hansen, T., Pedersen, O., Astrup, A., Ehrlich, S.D., \&Larsen, L. H.(2015). Specific gut microbiota features and metabolic markers in postmenopausal women with obesity. Nutrition and Diabetes, 5(6), e1597.

Candela, M., Biagi, E., Turroni, S., Maccaferri, S., Figini, P., \&Brigidi, P. (2015). Dynamic efficiency of the human intestinal microbiota. Critical Reviews in Microbiology, 41(2), 165-171. https://doi.org/10.3109/1040841X.2013.813900

Cani, P. D., Knauf, C., Iglesias, M. A., Drucker, D. J., Delzenne, N. M., \& Burcelin, R. (2006). Improvement of glucose tolerance and hepatic insulin sensitivity by oligofructose requires a functional glucagon-like peptide 1 receptor. Diabetes, 55(5), 1484-1490. https://doi.org/10.2337/db05-1360

Ceyhan, N., \& Alı̧, H.(2012). Bağırsak mikroflorası ve probiyotikler. Türk Bilimsel Derlemeler Dergisi, 5(1): 107-113.

Clarke, S.F., Murphy, E.F., O'Sullivan, O., Lucey, A.J., Humphreys, M., Hogan, A., Hayes, P., O'Reilly, M., Jeffery, I.B., Wood-Martin, R., Kerins, D.M., Quigley, E., Ross, R.P., O'Toole, P.W., Molloy, M.G., Falvey, E., Shanahan, F., \& Cotter, P.D.(2014). Exercise and associated dietary extremes impact on gut microbial diversity. Gut, 63(12), 1913-1920. https://doi.org/10.1136/gutjnl-2013306541

Chan, Y. K., Estaki, M., \& Gibson, D. L. (2013). Clinical consequences of diet-induced dysbiosis. Annals of Nutrition and Metabolism, 63(2), 28-40. https://doi.org/10.1159/000354902

Choque Delgado, G. T., \& Tamashiro, W. M. da S. C. (2018). Role of prebiotics in regulation of microbiota and prevention of obesity. Food Research International, 113(April), 183-188. https://doi.org/10.1016/j.foodres.2018.07.013

Collado, M. C., Derrien, M., Isolauri, E., De Vos, W. M., \& Salminen, S. (2007). Intestinal integrity and Akkermansia muciniphila, a mucin-degrading member of the intestinal microbiota present in infants, adults, and the elderly. Applied and Environmental Microbiology, 73(23), 7767-7770. https://doi.org/10.1128/AEM.01477-07

Collado, M. C., Isolauri, E., Laitinen, K., \& Salminen, S. (2008). Distinct composition of gut microbiota during pregnancy in overweight and normal-weight women. The American Journal of Clinical Nutrition, 88, 894-899. https://doi.org/10.1093/ajcn/88.4.894

Collado, M. C. ,Isolauri, E., Laitinen, K., \& Salminen, S. (2010). Effect of mother's weight on infant's microbiota acquisition, composition, and activity during early in fancy: a prospective. The American Journal of Clinical Nutrition, 92, 1023-1030. https://doi.org/10.3945/ajcn.2010.29877

Conlon, M. A., \& Bird, A. R. (2015). The impact of diet and lifestyle on gut microbiota and human health. Nutrients, 7(1), 17-44. https://doi.org/10.3390/nu7010017

Çolak, R. (2012). Tip 2 diabetes mellitus tedavisinde inkretinler. Deneysel ve Klinik Tlp Dergisi 29: 30-38. https://doi.org/10.5835/jecm.omu.29.s1.007 
Daglia, M. (2012). Polyphenols as antimicrobial agents. Current Opinion in Biotechnology, 23(2), 174-181. https://doi.org/10.1016/j.copbio.2011.08.007

Dao, M.C., Everard, A., Aron-Wisnewsky, J., Sokolovska, N., Prifti, E., Verger, E.O., Kayser, B.D., Levenez, F., Chilloux, J., Hoyles, L., Dumas, M.E., Rizkalla, S.W., Doré, J., Cani, P.D., \& Clément, K. (2015). Akkermansia muciniphila and improved metabolic health during a dietary intervention in obesity: Relationship with gut microbiomerichness and ecology. Gut, 65(3), 426-436. https://doi.org/10.1136/gutjnl-2014-308778

Derrien, M., Vaughan, E. E., Plugge, C. M., \& De Vos, W. M. (2004). Akkermansia municiphila gen. nov., sp. nov., a human intestinal mucin-degrading bacterium. International Journal of Systematic and Evolutionary Microbiology, 54(5), 1469-1476. https://doi.org/10.1099/ijs.0.02873-0

Derrien, M., Collado, M.C., Ben-Amor, K., Salminen, S., \& De Vos, W.M. (2008). The mucin degrader Akkermansia muciniphila is an abundant resident of the human intestinal tract. Applied and Environmental Microbiology, 74(5), 1646-1648. https://doi.org/10.1128/aem.01226-07

Derrien, M.,Passel, M. W. J. Van, Bovenkamp, J. H. B. Van De, Schipper, R. G., De Vos, W. M., \& Dekker, J. (2010). Structural mucin of intestinal mucus in human and mouse, Gut Microbes1(4), 254-268.

Derrien, M., Van Baarlen, P., Hooiveld, G., Norin, E., Müller, M., \& De Vos, W. M. (2011). Modulation of mucosal immune response, tolerance, and proliferation in mice colonized by the mucin-degrader Akkermansia muciniphila. Frontiers in Microbiology, 2, $1-$ 14. https://doi.org/10.3389/fmicb.2011.00166

Dubourg, G., Lagier, J. C., Armougom, F., Robert, C., Audoly, G., Papazian, L., \& Raoult, D. (2013). High-level colonisation of the human gut by Verrucomicrobia following broad-spectrum antibiotic treatment. International Journal of Antimicrobial Agents, 41(2), 149-155. https://doi.org/10.1016/j.ijantimicag.2012.10.012

Escobar, J. S., Klotz, B., Valdes, B. E., \& Agudelo, G. M. (2015). The gut microbiota of Colombians differs from that of Americans, Europeans and Asians. BMC Microbiology, 14(1), 1-14. https://doi.org/10.1186/s12866-014-0311-6

Everard, A.,Lazarevic, V., Derrien, M., Girard, M., Muccioli, G. G., Neyrinck, A. M., Possemiers, S., Holle, A.V., François, P., De Vos, W.M., Delzenne, N.M., Schrenzel, Jacques., \& Cani, P. D.(2011). Responses of gut microbiota and glucose and lipid metabolism to prebiotics in genetic obese and diet-induced leptin-resistant mice. Diabetes, 60(11), 2775-2786. https://doi.org/10.2337/db11$\underline{0227}$

Everard, A., \& Cani, P. D. (2013). Diabetes, obesity and gut microbiota. Best Practice and Research: Clinical Gastroenterology, 27(1), 73-83. https://doi.org/10.1016/j.bpg.2013.03.007

Everard, A., Belzer, C., Geurts, L., Ouwerkerk, J.P., Druart C., Bindels, L.B., Guiot, Y., Derrien, M., Muccioli, G.G., Delzenne, N.M., De Vos, W.M., \& Cani, P.D.(2013). Cross-talk between Akkermansia muciniphila and intestinal epithelium controls diet-induced obesity. Proceedings of the National Academy of Sciences, 110(22), 9066-9071. https://doi.org/10.1073/pnas.1219451110

Fabersani, E.,Russo, M., Marquez, A., Abeijón-Mukdsi, C., Medina, R., \& Gauffin-Cano, P. (2018). Modulation of intestinal microbiota and immuno metabolic parameters by caloric restriction and lactic acid bacteria. Food Research International. https://doi.org/10.1016/j.foodres.2018.06.014

Federico, A., Dallio, M., Di Sarno, R., Giorgio, V., \& Miele, L. (2017). Gut microbiota, obesity and metabolic disorders. Minerva Gastroenterologica E Dietologica, 63(4), 337-344.https://doi.org/10.23736/S1121-421X.17.02376-5

García-Peña, C., Álvarez-Cisneros, T., Quiroz-Baez, R., \& Friedland, R. P. (2017). Microbiota and Aging. A Review and Commentary. Archives of Medical Research, 48(8), 681-689. https://doi.org/10.1016/j.arcmed.2017.11.005

Gibson, P. R., \& Shepherd, S. J. (2005). Personal view: Food for thought-western lifestyle and susceptibility to Crohn's disease. The FODMAP hypothesis. Alimentary Pharmacology and Therapeutics, 21(12), 1399-1409. https://doi.org/10.1111/j.13652036.2005.02506.x

Goossens, D., Jonkers, D., Stobberingh, E., van den Bogaard, A., Russel, M., \& Stockbrügger, R. (2003). Probiotics in gastroenterology: Indications and future perspectives. Scandinavian Journal of Gastroenterology, 23, 15-23.

Goto, T., Edén, S., Nordenstam, G., Sundh, V., Svanborg-Edén, C., \& Mattsby, B.I. (1994). Endotoxin levels in sera of elderly individuals. Clinical and Diagnostic Laboratory Immunology, 1(6), 684-688.

Guarner, F., \& Malagelada, J.R. (2003). Gut flora in health and disease. Lancet, 361(9356), 512-519. https://doi.org/10.1016/S0140$\underline{6736(03) 12489-0}$

Guarner, F., Sanders, M.E., Eliakim, R., Fedorak, R., Gangl, A., Garisch, J., Kaufmann, P., Karakan, T., Khan A.G., Kim, N., Andrés De Paula, J., Ramakrishna, B., Shanahan, F., Szajewska, Hania., Thomson, A., \& Le Mair, A. (2017). Probiotics and prebiotics. World Gastroenterology Organisation Global Guidelines.

Halmos, E. P., Christophersen, C. T., Bird, A. R., Shepherd, S. J., Gibson, P. R., \& Muir, J. G. (2015). Dietsthatdiffer in their FODMAP contental terthe colonic luminal micro environment. Gut, 64(1), 93-100. https://doi.org/10.1136/gutjnl-2014-307264

Halmos, E. P., Christophersen, C. T., Bird, A. R., Shepherd, S. J., Muir, J. G., \& Gibson, P. R. (2016). Consistent prebiotic effect on gut microbiota with altered FODMAP intake in patients with Crohn's disease: A randomised, controlled cross-over trial of well-defined diets. Clinical and Translational Gastroenterology, 7(4), e164. https://doi.org/10.1038/ctg.2016.22

Han, J. L., \& Lin, H. L. (2014). Intestinal microbiota and type 2 diabetes: From mechanism insight stotherapeutic perspective. World Journal of Gastroenterology, 20(47), 17737-17745. https://doi.org/10.3748/wjg.v20.i47.17737

Hansen, C. H., Krych, L., Nielsen, D.S., Vogensen, F.K., Hansen, L.H., Sørensen, S.J., Buschard, K., \& Hansen, A.K. (2012). Early life treatment with vancomycin propagates Akkermansia muciniphila and reduces diabetes incidence in the NOD mouse. Diabetologia, 55(8), 2285-2294. https://doi.org/10.1007/s00125-012-2564-7

Haque, T. R., \& Barritt, A. S. (2016). Intestinal microbiota in liver disease. Best Practice and Research: Clinical Gastroenterology, 30(1), 133-142. https://doi.org/10.1016/j.bpg.2016.02.004

Hooper, L. V., \& Gordon, J. I. (2001). Commensal host-bacterial relationships in the gut. Science, 292(5519), 1115-1118. 
Kahn, S. E., Hull, R. L., \& Utzschneider, K. M. (2006). Mechanisms linking obesity to insulin resistance and type 2 diabetes. Nature, 444(712), 840. https://doi.org/10.1038/nature05482

Kanengoni, A. T., Chimonyo, M., Tasara, T., Cormican, P., Chapwanya, A., Ndimba, B. K., \& Dzama, K. (2015). A comparison of faecal microbial populations of South African Windsnyer-type indigenous pigs (SAWIPs) and Large White $\times$ Landrace $(\mathrm{LW} \times$ LR) crosses fed diets containing ensiled maize cobs. FEMS Microbiology Letters, 362(13), fnv100. https://doi.org/10.1093/femsle/fnv100

Karlsson, C. L. J., Önnerfält, J., Xu, J., Molin, G., Ahrné, S., \& Thorngren-Jerneck, K. (2012). The microbiota of the gut in preschool children with normal and excessive body weight. Obesity, 20(11), 2257-2261. https://doi.org/10.1038/oby.2012.110

Kemperman, R. A., Gross, G., Mondot, S., Possemiers, S., Marzorati, M., Van de Wiele, T., Doré, J., \& Vaughan, E. E. (2013). Impact of polyphenols from black tea and red wine/grape juice on a gut model microbiome. Food Research International, 53(2), 659-669. https://doi.org/10.1016/j.foodres.2013.01.034

Koçak, T., Şanlıer, N. (2017). Mikrobesin öğeleri ve mikrobiyota etkileşimi. Gümüşhane Üniversitesi Sağlık Bilimleri Dergisi, 6(4), 290-302.

Kong, C., Gao, R., Yan, X., Huang, L., \& Qin, H. (2018). Probiotics improve gut microbiota dysbiosis in obese mice fed a high-fat or high-sucrose diet. Nutrition, 60, 175-184. https://doi.org/10.1016/j.nut.2018.10.002

Koenig, J. E., Spor, A., Scalfone, N., Fricker, A. D., Stombaugh, J., Knight, R., Angenent, L.T., \& Ley, R. E. (2011). Succes sion of microbial consortia in the developing infant gut microbiome. Proceedings of the National Academy of Sciences, $108(1), 4578-4585$. https://doi.org/10.1073/pnas.1000081107

Koloğlu, S. (1996). Diabetes Mellitus. Endokrinoloji, Temel ve Klinik. Koloğlu S. (ed), Medical Network \& Nobel, Birinci Bask1, (s.368-385) içinde. Ankara.

Kuzu, F. (2017). Bağırsak mikrobiyotasının obezite, insülin direnci ve diyabetteki rolü. Journal of Biotechnology and Strategic Health Research, 1, 68-80.

Lee, H., \& Ko, G. (2014). Effect of metformin on metabolic improvement and gut microbiota. Applied and Environmental Microbiology, 80(19), 5935-5943. https://doi.org/10.1128/aem.01357-14

Lee, Y. K., \& Mazmanian, S. K. (2010). Has the microbiota played a critical role in the evolution of the adaptive immune system? Science, 330(6012), 1768-1773. https://doi.org/10.1126/science.1195568

Li, J., Lin, S., Vanhoutte, P.M., Woo, C.W., \& Xu, A. (2016). Akkermansia muciniphila protects against atherosclerosis by preventing metabolic endotoxemia-induced inflammation in Apoe-/- Mice. Circulation 133(24), 2434-2446. https://doi.org/10.1161/circulationaha.115.019645

Li, Z., Henning, S. M., Lee, R.-P., Lu, Q.-Y., Summanen, P. H., Thames, G., Corbett, K., Downes, J., Tseng, C.H., Finegold, S. M., \& Heber, D. (2015). Pomegranate extract induces ellagitannin metabolite formation and changes stool microbiota in healthy volunteers. Food \& Function, 6(8), 2487-2495. https://doi.org/10.1039/c5fo00669d

Liu, X., Fan, H., Ding, X., Hong, Z., Nei, Y., Liu, Z., Li, G., \& Guo, H. (2014). Analysis of the gut microbiota by high-throughput sequencing of the V5-Vv6 regions of the 16s rRna gene in donkey. Current Microbiology, 68(5), 657-662. https://doi.org/10.1007/s00284-014-0528-5

Mackowiak, P.A. (1982). The normal microbial flora. New England Journal of Medicine, 307(2),83-93. https://doi.org/10.1056/NEJM198207083070203

Manichanh, C., Reeder, J., Gibert, P., Varela, E., Llopis, M., Antolin, M., Guigo, R., Knight, R., \& Guarner, F. (2010). Reshaping the gut microbiome with bacterial transplantation and antibiotic intake. Genome Research, 20(10), 1411-1419. https://doi.org/10.1101/gr.107987.110

McLaughlin, T., Abbasi, F., Carantoni, M., Schaaf, P., \& Reaven, G. (1999). Differences in insulin resistance do not predict weight loss in response to hypocaloric diets in healthy obese women. The Journal of Clinical Endocrinology \& Metabolism 84(2): 578-581. https://doi.org/10.1210/jcem.84.2.5441

McLaughlin, T. L., \& Reaven, G. M. (2003). Beyond type 2 diabetes: The need for a clinically useful way to identify insulin resistance. The American Journal of Medicine, 114(6), 501-502. https://doi.org/.1016/s0002-9343(03)00122-0

Napolitano, A., Miller, S., Nicholls, A. W., Baker, D., Van Horn, S., Thomas, E., Rajpal, D., Spivak, A., Brown, J.R., \& Nunez, D. J. (2014). Novel gut-based pharmacology of metformin in patients with type 2 diabetes mellitus. PLoS ONE, 9(7), 1-14. https://doi.org/10.1371/journal.pone.0100778

Nauck, M., Frid, A., Hermansen, K., Shah, N. S., Tankova, T., Mitha, I. H., Matthews, D. R., \& for the LEAD-2 Study Group (2009). Efficacy and safety comparison of liraglutide, glimepiride, and placebo, all in combination the LEAD ( Liraglutide Effect and Action in Diabetes )- LEAD 2 study. Diabetes Care, 32(1), 84-90. https://doi.org/10.2337/dc08-1355.Clinical

Neyrinck, A. M., Etxeberria, U., Taminiau, B., Daube, G., Van Hul, M., Everard, A., Cani, P.D., Bindels L. B., \& Delzenne, N. M. (2017). Rhubarb extract prevents hepatic inflammation induced by acute alcohol intake, an effect related to the modulation of the gut microbiota. Molecular Nutrition and Food Research, 61(1), 1-12. https://doi.org/10.1002/mnfr.201500899

Onkamo, P., Väänänen, S., Karvonen, M., \& Tuomilehto, J. (1999). Worldwide increase in incidence of type I diabetes - The analysis of the data on published incidence trends. Diabetologia, 42(12), 1395-1403. https://doi.org/10.1007/s001250051309

Org, E., Parks, B.W., Joo, J.W., Emert, B., Schwartzman, W., Kang, E.Y., Mehrabian, M., Pan, C., Knight, R., Gunsalus, R., Drake, T.A., Eskin, E., \& Lusis A.J. (2015). Genetic and environmental control of host-gut microbiota interactions. Genome Research, 25(10), 1558-1569. https://doi.org/10.1101/gr.194118.115

Ottman, N., Geerlings, S. Y., Aalvink, S., De Vos, W. M., \& Belzer, C. (2017). The discovery of Akkermansia muciniphila has opened new avenues for the use of this. Best Practice \& Research Clinical Gastroenterology. https://doi.org/10.1016/j.bpg.2017.10.001

Overton, H.A., Babbs, A.J., Doel, S.M., Fyfe, M.C., Gardner, L.S., Griffin, G., Jackson, H.C., Procter, M.J., Rasamison, C.M., TangChristensen, M., Widdowson, P.S., Williams, G.M., \& Reynet, C.(2006). Deorphanization of a G protein-coupled receptor for 
oleoylethanolamide and its use in the discovery of small-molecule hypophagic agents. Cell Metabolism, 3(3), 167-175. https://doi.org/10.1016/j.cmet.2006.02.004

Overton, H.A., Fyfe, M.C., \& Reynet, C. (2008) . GPR119, a novel G protein-coupled receptor target for the treatment of type 2 diabetes and obesity. British Journal of Pharmacology 153 (1), 76-81. https://doi.org/10.1038/sj.bjp.0707529

Özden, A. (2006). Sağlıklı Yaşam İçin Yararlı Dost Bakteriler. Türk Gastroentoloji Vakfı Yayınları, Ankara.

Özyurt, V. H. \& Ötles, S.(2014). Properties of probiotics and encapsulated probiotics in food. Acta Scientiarum Polonorum, Technologia Alimentaria, 13(4), 413-424. https://doi.org/10.17306/J.AFS.2014.4.8

Parkar, S. G., Stevenson, D. E., \& Skinner, M. A. (2008). The potential influence of fruit polyphenols on colonic microflora and human gut health. International Journal of Food Microbiology, 124(3), 295-298. https://doi.org/10.1016/j.ijfoodmicro.2008.03.017

Pérez-Cobas, A. E., Gosalbes, M. J., Friedrichs, A., Knecht, H., Artacho, A., Eismann, K., Otto, W., Rojo, D., Bargiela, R., von Bergen, M., Neulinger, S.C., Däumer, C., Heinsen, F.A., Latorre, A., Barbas, C., Seifert, J., dos Santos, V.M., Ott, S.J., Ferrer, M., \& Moya, A.. (2014). Gut microbiota disturbance during antibiotic therapy: A multi-omic approach. Gut Microbes, 5(1), 64-70. https://doi.org/10.4161/gmic. 27128

Reid, G., Younes, J. A., Van Der Mei, H. C., Gloor, G. B., Knight, R., \& Busscher, H. J. (2011). Microbiota restoration: Natural and supplemented recovery of human microbial communities. Nature Reviews Microbiology, 9(1), 27-38. https://doi.org/10.1038/nrmicro2473

Reid, D. T., Eller, L. K., Nettleton, J. E., \& Reimer, R. A. (2016). Postnatal prebiotic fibre intake mitigates some detrimental metabolic outcomes of early overnutrition in rats. European Journal of Nutrition, 55(8), 2399-2409. https://doi.org/10.1007/s00394-015$1047-2$

Roberfroid, M., Gibson, G., Hoyles, L., McCartney, A., Rastall, R., Rowland, I., Wolvers, D., Watzl, B., Szajewska, H., Stahl, B., Guarner, F., Respondek, F., Whelan, K., Coxam, V., Davicco, M.J., Léotoing, L., Wittrant, Y., Delzenne, N.M., Cani, P.D., \& Ne, A. (2010). Prebiotic effects: Metabolic and health benefits. British Journal of Nutrition, 104(2), 1-63. https://doi.org/10.1038/159869b0

Rodes, L., Khan, A., Paul, A., Coussa, C. M., Marinescu, D., Tomaro D. C., Shao,W., Kahouli, I., \& Prakash, S. (2013). Effect of probiotics Lactobacillus and Bifidobacterium on gut-derived lipopolysaccharides and inflammatory cytokines: an in vitro study using a human colonic microbiota model. Journal of Microbiology and Biotechnology, 23(4), 518-526.

Roopchand, D. E., Carmody, R. N., Kuhn, P., Moskal, K., Rojas-Silva, P., Turnbaugh, P. J., \& Raskin, I. (2015). Dietary polyphenols promote growth of the gut bacterium Akkermansia muciniphila and attenuate high fat diet-induced metabolic syndrome. Diabetes, 64(8), 2847-2858.

Santacruz, A., Collado, M., García-Valdés, L., Segura, M., Martín-Lagos, J., Anjos, T., Martí-Romero, M., Lopez, R.M., Florido, J., Campoy, C., \& Sanz, Y. (2010). Gut microbiota composition is associated with body weight, weight gain and biochemical parameters in pregnant women. British Journal of Nutrition, 104(1), 83-92. https://doi.org/10.1017/S0007114510000176

Schley, P. D., \& Field C.J. (2003). The immune-enhancing effects of dietary fibres and prebiotics. British Journal of Nutrition, 87(6), 221-230. https://doi.org/10.1079/bjnbjn/2002541

Schwiertz, A., Taras, D., Schäfer, K., Beijer, S., Bos, N. A., Donus, C., \& Hardt, P. D. (2010). Microbiota and SCFA in lean and overweight healthy subjects. Obesity, 18(1), 190-195. https://doi.org/10.1038/oby.2009.167

Shin, N. R., Lee, J. C., Lee, H. Y., Kim, M. S., Whon, T. W., Lee, M. S., \& Bae, J. W. (2014). An increase in the Akkermansia spp. population induced by metformin treatment improves glucose homeostasis in diet-induced obese mice. Gut, 63(5), 727-735. https://doi.org/10.1136/gutjnl-2012-303839

Tailford, L. E., Crost, E. H., Kavanaugh, D., \& Juge, N. (2015). Mucin glycan foraging in the human gut microbiome. Frontiers in Genetics, 6(81). https://doi.org/10.3389/fgene.2015.00081

Tannock, G. W., Munro, K., Harmsen, H. J. M., Welling, G. W., \& Smart, J. (2000). Analysis of the fecal microflora of human subjects consuming a probiotic product containing Lactobacillus rhamnosus DR20. Applied and Environmental Microbiology, 66(6), 25782588. https://doi.org/10.1128/aem.66.6.2578-2588.2000

Tekin, T., Çiçek, B., \& Konyalıgil, N. (2018). İntestinal mikrobiyota ve obezite ilişkisi. Sağllk Bilimleri Dergisi, 27, 95-99.

Yetkin, İ., Satış, H., \& Satış, N. K. (2017). Bağırsak mikrobiyotasının insülin direnci, diabetes mellitus ve obezite ile ilişkisi. Türkiye Diyabet ve Obezite Dergisi, 1: 1-8.

Yılmaz, K., \& Altındiş, M. (2017). Sindirim sistemi mikrobiyotasi ve fekal transplantasyon. Nobel Medicus, 13(1), 9-15.

Zhang, X., Shen, D., Fang, Z., Jie, Z., Qiu, X., Zhang, C., Chen, Y., \& Ji, L. (2013). Human gut microbiota changes reveal the progression of glucose intolerance. PLoS ONE, 8(8), e71108. https://doi.org/10.1371/journal.pone.0071108

Zhou, Z. Y., Ren, L. W., Zhan, P., Yang, H. Y., Chai, D. D., \& Yu, Z. W. (2016). Metformin exerts glucose-lowering action in high-fat fed mice via attenuating endotoxemia and enhancing insulin signaling. Acta Pharmacologica Sinica, 37(8), 1063-1075. https://doi.org/10.1038/aps.2016.21

Zhou, K. (2017). Strategies to promote abundance of Akkermansia muciniphila, an emerging probiotics in the gut, evidence from dietary intervention studies. Journal of Functional Foods, 33, 194-201. https://doi.org/10.1016/j.jff.2017.03.045 